\title{
The Socialisation of Migrant Children in Transnational Settings*
}

\author{
EVELINE REISENAUER** \\ German Youth Institute, Munich
}

\begin{abstract}
This article argues that it is central to consider the socialisation processes of migrant children in transnational settings when focusing on issues of integration and the transnationality of the next generation. A central experience of migrant children is that they grow up and are involved in both the emigration and immigration country (of their parents). Many of them circulate between Germany and Turkey several times and maintain multiple relationships across national borders when they are growing up. This has implications for their family relationships and educational careers in childhood, but beyond that it also has effects that are detectable into adulthood. The article shows that migrant children develop the potential and skills that enable them to live a transnational life. The question the article therefore addresses is whether and how a transnational childhood affects the transnationality and integration of the next generation in the adult life.
\end{abstract}

Keywords: transnationality, integration, migrant children, next generation, socialisation

Sociologický časopis / Czech Sociological Review, 2022, Vol. 58, No. 1: 7-27

https://doi.org/10.13060/csr.2022.012

\section{Introduction: the next generation in migration processes}

Cross-border activities in migration contexts are broadly considered a one-generation phenomenon. 'Often discussions of the second generation implicitly assume that migration stops after the first generation.' [Fouron, Glick Schiller 2001: 64] Consequently, research on the 'next generation', the children of immigrants, has mainly focused on aspects of integration into the immigration country. Educational performance in particular is therefore seen as an important indicator of the next generation's integration [Alba, Holdaway 2013]. While migration studies

\footnotetext{
* This paper has been developed on the basis of research conducted in two projects. TRANS-NET was supported by the European Union's 7th Framework Programme FP7/2008-2011 under Grant 217226. DIWAN was funded by the German Federal Ministry of Education and Research (BMBF) under the funding code 01UM1814AY as part of the 'Migration and Social Change' initiative.

** Direct all correspondence to: Eveline Reisenauer, German Youth Institute, Nockherstraße 2, 81541 Munich, Germany, e-mail: reisenauer@dji.de.
}

(C) Sociologický ústav AV ČR, v. v. i., 2022

(C) Author, 2022 
have long neglected the transnational experiences of children and youth in migration processes, child-centred research in this field has gained increased attention in recent years [Gardner 2012; White et al. 2011]. More recent studies based on transnational approaches question whether transnationality relates solely to people with direct migration experience, or whether it also affects second and later generations of migrants [Levitt, Waters 2002b]. While quantitative studies show that only a minority of migrant children are transnationally active, qualitative studies highlight the complexity of transnational ties among the generations that follow [Fürstenau, Niedrig 2007].

Thomas Faist [2000] has noted in reference to Turkish-German migration that transnationality is not limited to the first generation of migrants. Rather, transnational social spaces develop in two stages. In the first stage, transnationality must be seen as a by-product of international migration. Turkish migrants did not lose their ties to Turkey when they migrated to Germany. In fact, there was a continuous exchange going on between Turkey and Germany. Turks who migrated to Germany did so to provide for their family in Turkey, and consequently transnational family constellations are typical for first-generation migrants. In the second stage, transnational social spaces go beyond the first generation and develop a life of their own. The second generation not only continues the existing cross-border relations of their parents, they also establish their own ties to Turkey. Based on Thomas Faist's conceptualisation of social spaces and the transnationality of the next generation, this article investigates the transnational experiences of Turkish migrant children in more detail (Part I) and shows how transnationality continues into adulthood (Part II).

Below I draw on empirical findings from the German part of the TRANSNET project (2008-2011) and combine them with more theoretical considerations from the project DIWAN (2018-2021). 'Transnationalisation, Migration and Transformation: Multi-Level Analysis of Migrant Transnationalism' (TRANS-NET) is the title of a research project that focused on transnationalisation processes in the political, economic, sociocultural, and educational spheres in different country constellations (Estonia/Finland, India/UK, Morocco/France, and Turkey/Germany) [Pitkänen, Içduygu, Sert 2012]. The focus of the German part of TRANSNET at Bielefeld University was to investigate transnational practices within the frame of Turkish-German migration [Gerdes, Reisenauer, Sert 2012]. In this study, seventy-three qualitative interviews were conducted with 'Turkish migrants' and their descendants in Germany. Below, the term 'Turkish migrants' is used to refer to persons who came from Turkey and migrated to Germany, but that does not necessarily mean that they consider themselves Turkish. Thus, regardless of the ethnic and religious diversity of the respondents, the focus of this study is on their common migration experience. The respondents who were interviewed include former 'guest workers', marriage migrants, family-based migrants, German-born children of Turkish migrants, asylum seekers, international students, and high-skilled labour migrants. The TRANS-NET project thus provides insight 
on the children of Turkish migrants from the 'Gastarbeiter' or 'guest worker' era in Germany. However, they are diverse not only in terms of their ethnic self-attribution and (familial) migration experience but also in terms of factors unrelated to migration, such as educational level, socioeconomic status, age, and gender. In this article the empirical findings on transnational experiences during childhood and in the further life course are not based on children's narratives but on the retrospective narratives of the adult children of migrant parents. Different experiences of socialisation in transnational settings are interpreted from an adult vantage point. However, analysing narratives told by adult migrant children provides rare insight into their reflections on transnational experiences in childhood and the continuation of transnational practices from childhood throughout adult life. In this respect, retrospective accounts of migration processes can be seen as 'a fruitful way to examine the impact of childhood experiences on adult lives' [Phoenix 2010].

A new perspective on the narratives of adult migrant children from the TRANS-NET project is provided by insights from the project 'Diversity and Change of Parenting in Migration Families' (DIWAN), conducted at the German Youth Institute. This project devotes particular attention to socialisation processes in migration contexts. While TRANS-NET was actually focused very broadly on transnationalisation, DIWAN opens up a way to reflect on how migration and transnational processes influence the socialisation of children and their adult life.

\section{Part I: Transnational childhoods}

\section{Being a migrant child: living out of a suitcase}

The migration patterns that Germany's 'guest worker' recruitment gave rise to from the beginning of the 1960s resulted in a considerable number of children of Turkish migrants growing up in a transnational setting. Initially, most Turkish first-generation 'guest workers' migrated to Germany alone and left their family and relatives behind in Turkey. They went to Germany mainly for economic reasons, hoping to increase their income and thereby also the living conditions of family members in Turkey. Most of the former Turkish labour migrants interviewed in the TRANS-NET project said that they used to send some of their income back home to Turkey, where the money was used by their nuclear or extended family to cover monthly expenses and to make investments. They tried to save enough money to build a house, buy an apartment, or start a small business after returning to Turkey.

Some Turkish migrants ultimately went back to Turkey, either because they were offered financial incentives by the German government to do so or for personal reasons, such as unemployment or xenophobia in Germany, or because of family commitments in Turkey [Abadan-Unat 1988; Martin 1991]. Although the 
employment of Turkish workers was meant to be temporary, ${ }^{1}$ many of these workers remained in Germany, which also had an impact on their family. With the introduction of the family reunification act in Germany in 1972, more and more Turkish migrants began arranging for their spouse and underage children to join them in Germany. The lowering of the age limit for children to join their parents from 18 to 16 on the German side and the warlike conditions that followed the military putsch on the Turkish side are important factors that led Turkish migrants to consider the opportunity to bring their children to Germany at the beginning of the 1980s. One of the interviewees from the 1.5 generation ${ }^{2}$ who described his family reunification is Bülent:

My father came to Kaiserslautern (a town in Germany - author's note) in 1969 and he moved within Germany in 1979. At that point he decided, 'either I go back or I'll bring my whole family' - after ten years. And he decided to bring his family. Therefore, my mother, my three siblings, and I came to Germany before the end of the year 1979. From a small village close to the Black Sea in the northeast of Turkey. (Bülent, 22, 4) ${ }^{3}$

As Bülent's case shows, male 'guest workers' in particular moved to Germany alone for occupational reasons and stayed in Germany for years without their family members before they decided to bring them. A study by Sonja Haug [2005: 85-86] points out that the immigration year of respondents in the 1.5 generation more often matches the immigration year of their mother than that of their father. This indicates that Turkish migrant children more often migrated with their mother to Germany or at least within a short time after her. However, there are also cases where children initially stayed in Turkey with their father, while the mother migrated to Germany in search of work [Erel 2002].

Even in cases where migrants brought their whole family with them to Germany, the 'return orientation', that is, the idea that the family would one day go back to Turkey, was not necessarily abandoned. Rather, families continued to expect that their life in the immigration country would be part of a transition period and, thus, did not see their future in Germany. In many cases this meant that the return orientation continued to exist for a long time, while the migrant

\footnotetext{
${ }^{1}$ From the outset, the recruitment of Turkish 'guest workers' was regarded as temporary migration. 'The assumption that these "guestworkers' would eventually return was initially shared on all sides.' [Joppke 1999: 65] This includes the German government, the sending states, and the 'guest workers' themselves.

2 While second and third generations are people who were born in the country their parents or grandparents migrated to, the 1.5 generation refers to children who were born in the emigration country and arrived in the immigration country as children or adolescents. 3 All cited quotations are derived from the German TRANS-NET study. For each quotation, the pseudonym of the interviewee, the participant number, and the line number in the interview transcript are provided. The quotations are translated by the author.
} 
family stayed in Germany. Accordingly, the children of these migrants grew up in Germany also believing their family would return to Turkey in the near future. What this meant and how it might have felt to be a migrant child during the 'guest worker' era in Germany is vividly described in Dilek's narrative:

\begin{abstract}
Yes, and then it (the planned return migration of the family - author's note) was postponed to the next year. In this respect, in a sense, we lived out of our suitcases. Everything was prepared for returning next summer. The money was saved, saved, and saved. 'Next year we will go back forever.' That had a negative effect on me, because you cannot set yourself proper goals. In addition, in terms of education, career plans, or friendships, I didn't want my emotional ties to become too strong, because I kept thinking that I'd be going back the following year anyway. As far as these things were concerned, I never really felt at home. (Dilek, 55, 4)
\end{abstract}

The migration history of Dilek's family started when her father came to Germany in 1972. Before migrating, the family bought a house in Turkey and Dilek's father wanted to work in Germany to save some extra money in order to become selfemployed in Turkey. While Dilek's father was working and living in Germany, her mother felt seriously ill. Since the doctors in Turkey could not help her, she was brought to Germany for additional examinations in order to determine a diagnosis. Her children accompanied her. Once it became clear that the mother would have to stay three months in the hospital, Dilek's father decided to send the children to a German school. This was followed by constantly new reasons for staying in Germany, while always retaining the initial idea of returning to Turkey. The result of this, as Dilek puts it, was that it was like living out of a suitcase.

A lasting return orientation affected more than just the way of life of migrant families in Germany. 'Planning to return at the moment of migration has a positive and significant effect on engaging in transnational practices.' [Itzigsohn, Saucedo 2002: 782-785] As the narratives of former Turkish migrant children revealed, there was a correlation between enduring plans to move back to Turkey and continued ties to that country. Turkish migrant families continued to be actively engaged in their home country in order to pursue their dream of a better life there. For example, migrants sent remittances to their extended family back home, became property-owners in Turkey with the intention of settling there in the future, or invested capital in a business in Turkey.

Migrant families that maintained a return orientation while living in Germany became transnational actors. Particularly the children of Turkish migrants thereby came to have childhoods characterised by transnational practices. The interviews reveal that the mobility of migrant children, among other transnational practices, is especially striking. These children were not only affected by the emigration of their mother or father to Germany, they also showed a high level of mobility themselves. Multiple moves back and forth between Turkey and Germany can be observed in the individual biographies of members of the next generation. An illustration of this is provided by Nilay's migration history: 
I came (to Germany - author's note) as a child at the age of two or three. I lived around three, four years here and then I was here in school for the first and second grades. Then I was back in Turkey. I lived with my grandma for around two years, together with my sister, while my other siblings were here. We went to our grandma because she was alone. We lived there for two years, then my sister stayed but I was here (in Germany - author's note) for one year. And then I travelled to Turkey, because my sister didn't want to remain there since she wanted to go to the parents. She came and I went to Turkey where I stayed for another year. And afterwards, I think it was 1976, I came and since then I've been in Germany. (Nilay, 24, 46)

The case of Nilay demonstrates that among many migrant children their main place of residence changed repeatedly in response to new situations. A considerable proportion of the respondents who were migrant children had spent long periods of their lives in both Turkey and Germany. While their parents initially migrated, they remained in the care of their grandparents and were only brought to Germany later. Others were born in Germany but were sent to Turkey to be raised there. Migrant children also crossed borders repeatedly for holidays and family events, such as birthdays or weddings. On the whole, migrant children and young people move back and forth repeatedly between the immigration and emigration country (of their parents) [Apitzsch, Siouti 2008; Reisenauer 2015], thereby becoming extremely mobile actors [Fog Olwig 2012]. The mobility of migrant children turns migration into not a singular occurrence but rather as an ongoing and recurring process in the life course. This calls attention to both the continuities and the dynamics of transnational (nuclear and extended) families.

\section{Experiences of separation and reunification: challenges for migrant families}

The case of Turkish 'guest worker' migration to Germany indicates how the lives of migrant families can become so entangled with the migration process. 'The strong effects of transnational labour on family life have become increasingly evident as more family members seek employment across national boundaries. Around the world, families are becoming more dispersed. Families are transnationally located, spread out over several countries and continents.' [Gjokaj, Baca Zinn, Nawyn 2013: 284-286] Children's separation from their parents is a particularly common phenomenon in migration. For example, a study carried out in the United States among children from China, Central America, the Dominican Republic, Haiti, and Mexico found that among the 385 children interviewed, 85\% had been separated from one or both parents during the process of migration [Suârez-Orozco, Todorova, Louie 2002].

The children of Turkish migrants also experienced separation from their reference persons. 'The second generation experienced a separation from at least one parent. They were often left for years to grow up with relatives and then had to leave the relatives to go to Germany - following their parents from whom they 
were estranged, since they saw them only once a year during a holiday.' [ZielkeNadkarni 2003: 170] Moreover, as shown above, migrant children moved several times between Turkey and Germany. This circulation meant that the migrant children experienced not only a recurring geographical relocation but also multiple and repetitive separations from and reunifications with members of their nuclear and extended family [Reisenauer 2015].

In this regard, Bilge's narrative is representative of that of other Turkish migrant children interviewed in the TRANS-NET project. Bilge's parents migrated to Germany when Bilge was an infant. During the absence of their parents, their grandmother in Turkey raised Bilge and her brother. The siblings did not then migrate together, as Bilge moved to Germany first:

Well, I was born in 1979 in Turkey and came here (to Germany - author's note) at the age of six. My parents were already living here ... and they brought my brother and me over five, six years later. (...) Until the age of six years I was with my grandma in Turkey. (...) Well, I have to say, I was one year without my brother, he came one year later. (Bilge, 23, 4)

As this passage demonstrates, when migrant children followed their parents to Germany, they experienced a 'double disruption of ties' [Wilhelm 2011]. First, they were separated from one or both parents who migrated to Germany, and then they had to leave other family members in Turkey when they, too, moved to Germany. Thus, depending on their present location, Turkish migrant children were faced with a spatial separation from either their siblings, parents, grandparents, or other relatives. In Bilge's case, moving to Germany brought her closer to her parents, but separated her from her brother and grandmother in Turkey. The multiple moves of migrant children across national borders were accompanied by constant fluctuations in their physical proximity to significant others. As a result, these children, moving back and forth, maintained various long-distance and cross-border relationships with family members, relatives, and friends.

While the empirical evidence on transnational families in migration is well documented, different findings have been reached as to what the consequences of spatial and cross-border separations are for the family members involved and for the family as a whole. On the one hand, scholars have highlighted the continuity of 'familyhood' in migration processes [Bryceson, Vuorela 2002] and have argued that spatial disruptions do not lead to the break-up of family relations, and rather that reciprocal exchanges between family members take place 'across and despite the distance that separates them' [Baldassar, Merla 2014a]. The persistence of family intimacy over large spatial distances can be attributed to the fact that family responsibilities do not disappear in the face of migration. ${ }^{4}$ On

${ }^{4}$ Financial remittances from migrants are a significant source of support for family members, relatives, and friends in the emigration country [Guarnizo 2003; Goldring 2004], 
the contrary, the spatial dispersion of the family as a migration strategy is in this sense seen as 'a rational family decision to preserve the family, a resourceful and resilient way of strengthening it: families split in order to be together translocally' [Chan 1997]. On the other hand, some scholars have questioned the emotional attachment in transnational families by referring to the emotional costs of the spatial separation of family members. According to this view, migrant families have a hard time balancing their lives between the immigration and emigration countries. The financial security provided by labour migration comes at the price of greater emotional insecurity [Parreñas 2001]. Thus, transnational families are mainly associated with a negative impact on the well-being of children [Mazzucato, Schans 2011; Rohr, Jansen, Adamou 2014].

Separations and reunifications were also found to have far-reaching consequences on nuclear and extended family members in the context of TurkishGerman migration. This is especially evident in cases where the migrant children were initially left behind in Turkey and followed their migrant parents to Germany later [Reisenauer 2015]. The narratives of former migrant children provide insight into the effects that such separations have on future parent-child relationships. Even with migrant children's strong desire for reunification with their parents, the ultimate reunification of a family could be an experience that produced mixed feelings. Living together after several years of separation posed diverse challenges for all the family members involved. From the perspective of the migrant children, migration to Germany and living together with their parents and siblings meant experiencing 'close strangers'. Furthermore, the reunification of (parts of) the nuclear family in Germany not only dissolved the transnational family constellation, it also simultaneously created a new cross-border family arrangement. As a result of having emigrated from Turkey, migrant children had to deal with spatial separations from their grandparents and other relatives, which they experienced as a painful process. The grandparents who had cared for them in particular became an important part of the children's lives after their natural parents migrated to Germany. In this regard, migrant children experienced 'distant intimates'.

\section{Attendance at school here and there: challenges for educational careers}

The repeated geographical relocation of Turkish migrant children not only puts them in a position of continuously re-adapting to changing family arrangements, it also has effects on their entire educational pathways. On the whole, the children

especially in the case of migrants who have minor children in the home country [Holst, Schäfer, Schrooten 2012]. Moreover, family responsibilities are expressed through the provision of assistance and care across national borders [Baldassar, Merla 2014b]. Above all, migrant mothers continue to actively care for the children they left behind [HondagneuSotelo, Avila 1997; Parreñas 2001; Goulbourne et al. 2010]. 
of 'guest workers' who did not spend their early childhood in Germany consider their late arrival in Germany an obstacle to their progress at school [Filsinger 2011]. Insufficient knowledge of the German language in particular is seen as a serious problem [Esser 2006], as in the case of Emre, who followed his parents to Germany when he was of primary school age.

Then I went to primary school here (in Germany - author's note), third, fourth grade. Of course, I had difficulties. I was able to speak at least some German, since I'd been in Germany for a short time when I was five years old. But I couldn't do the written examinations you had to do. (...) Well, in any case, I've been somewhat in-between in school, I could speak but couldn't write properly. So I had difficulties and attended (a vocation-oriented - author's note) secondary school (Hauptschule). (Emre, 27, 12)

Just like the first arrival in Germany, future movements between Turkey and Germany also had consequences for the migrant children. A study on children who returned to Turkey from Germany found that some Turkish migrant children changed schools across borders not only once, but several times in their educational career [Stenzel, Homfeldt 1985]. And the German TRANS-NET study also shows several interruptions in the educational pathways of the 1.5 and second generation in Germany. One of such case is Nilay, who was born in Turkey in 1964. Her father went to Germany to work the year she was born. One year later, he brought his wife to Germany, and another year later he brought his four children, including Nilay. Two more children were born in Germany. Nilay commuted several times between Turkey and Germany. She attended the first and second grades at a school in Germany. After that she went back to Turkey with her sister and was cared for by her grandmother. Her sister remained there, while Nilay migrated to Germany again. Commuting between Turkey and Germany continued for a while during her childhood, and she is unable to reconstruct how many times she has crossed the border and changed schools. She describes one of her re-entries into the German school system as follows:

I went to a German school and attended the seventh, eight, and ninth grades there. Before entered seventh grade - how can I put it - I had to learn German for a year since I'd been travelling back and forth. So I had to attend a class just for learning German. Afterwards I directly entered seventh grade and that was really terrible, that was really hard for me. The other pupils had already dealt with the relevant topics and I wasn't able to catch up. I'd always been travelling back and forth, had been two years here and then one year there to attend a Turkish school, and so on. (Nilay, 24, 274)

Nilay experienced the time when she was being sent back and forth between two countries by her parents as very difficult for her educational pathway. Her situation only improved after she permanently migrated to Germany in 1976. From 
then on, she attended just one school and had no further interruptions in her educational path. This gave her the opportunity to complete her secondary education with a qualification.

Migrant children had similar experiences during the transition to work. This, too, is strongly influenced by individual migration contexts. An example is the case of Sinan, who came to Germany in 1980 when he was fifteen years old:

\begin{abstract}
After school I did not do any training for a profession. I only did that later on. Because at the time my father said to me, 'It's not worth learning a profession, since we'll return (to Turkey - author's note) in a few years, in one or two years'. (...) Then we were here for three more years and I still hadn't started a profession. And finally, we remained in Germany. Then I started working at a company. Only later did I start training for a profession as a specialist packer at the same company, and I've completed it. And I'm still with the company, for 24 years, a long time. (Sinan, 29, 8)
\end{abstract}

Sinan worked as an unskilled shopkeeper while he waited for his family's declared plan to return to Turkey, and then he finally pursued professional training as a specialist packer. In the data material there are many narratives from migrant children that show how they had to make up for a neglected education later. This relates to both school education and professional training. The educational and professional development of migrant children indicates that the initially negative impact transnationality can have on education and integration may also lead to positive outcomes [Apitzsch, Siouti 2008; Fürstenau 2008].

\title{
Part II: The continuation of transnationality into adulthood
}

\section{The effects in adult life of having been a migrant child}

For some Turkish migrants in Germany under the 'guest worker' regime, what was originally supposed to be temporary labour migration turned into permanent settlement there. In such cases the return orientation remained an illusion [Pagenstecher 1996]. For example, Halil was born in Germany, where his father worked with the intention to save enough money to buy a tractor upon their return to Turkey. However, the family never went back, a situation that Halil summed up as follows: 'Two generations for one tractor ...' (Halil, 43, conversation after the recording)

While the interviews with former migrant children clearly revealed the significance of migration and transnationalisation processes in their lives, it is not yet clear what place transnationality occupies in or how it affects their lives after the transition to adulthood. On this, existing studies have come to different conclusions. On the one hand, a decrease in transnational activities can be identified that can be traced to the requirements of adult life, which includes responsibilities such as work and children, among others, that leave little time for travelling 
and other transnational practices [Jones-Correa 2002; Smith 2002]. On the other hand, transnationality is also visible during the adulthood of migrant children. Phenomena such as marrying a partner from the (parents') emigration country [Schmidt 2011; Straßburger 2004] or the so-called second-generation return [King, Christou 2010] are evidence of this.

The German part of the TRANS-NET project supports the existence of both trajectories, as for some former migrant children Turkey loses its significance over time, while others continue or even increase their transnational practices in adult life. Thus, transnationality after the transition from childhood to adulthood is characterised by different tendencies. Nevertheless, against a backdrop of migration research and integration studies that sees transnationality as mainly a onegeneration phenomenon, it is worth noting that a significant proportion of adult migrant children remain oriented towards both countries, Germany and Turkey. How transnationality shaped the biographies of Turkish migrant children into adulthood is still evident in the narratives of the respondents in the TRANS-NET project. A transnational childhood helps to explain why former migrant children keep moving and acting between two (or even more) countries later in life. Their parents' repeated postponement of the family's return to Turkey and their own transnational experiences in childhood had consequences for their personal relationships, educational and occupational careers, and life plans. Most notably, 'the social relationships which children build during their childhood can aid understanding of the continuity of transnational engagement in the adult second generation' [Haikkola 2011: 1202].

The narrative of a woman named Petek provides information on how the effect of transnationality on personal relationships in childhood also has an impact in adulthood. Petek's grandparents and one of her aunts returned to Turkey when Petek still was an infant. She consequently grew up in a transnational family arrangement in which she developed routinised ways of acting across national borders over the years. For example, when her father died prematurely, she experienced geographical distance as no obstacle to organising a collective family farewell.

\footnotetext{
Also at that time, when my father was in his final days, we flew his sisters in from Turkey, having applied for a visa for them. After that, one thing followed another, they were then here (in Germany - author's note) for two months. We spared no effort in preparing everything that was even possible. (...) You have to be flexible. So, we know it like that, we grew up with that. (Petek, 08, 147)
}

Because Petek had these and similar experiences in childhood, a transnational family life has become the norm for her. She consequently grew up 'learning that physical mobility is an integral, if not always an enjoyable, aspect of life' [Fog Olwig 2012: 949]. As an adult, she is still conscious of building on proven routines of transnationality when necessary. For example, if her grandparents were to need 
care, Petek would know how to immediately arrange to be with her grandparents to see to their needs. Petek's narrative about her family life as a migrant child suggests that earlier and later transnational practices are interconnected.

This is also reflected in the literature on international students. It has been found that students who study abroad often have past international experiences. Many international students have already had encounters with other countries and cultures before they study abroad, in some cases because of their international family background [Carlson 2013]. Moreover, studying abroad further increases the probability of international labour market mobility in the future [King, Ruiz-Gelices 2003: 245; Parey, Waldinger 2008]. If transnational practices at various times must be seen in conjunction with each other, it needs to be clarified what connects them. Below I argue that current practices build on and extend potential and skills for living transnationally that individuals have developed in the past.

\section{The potential and skills for living transnationally}

Turkey has become closer in terms of time. I don't consider it a big step to fly three hours. And then I already know where I have to go when I arrive in Istanbul, I know how to arrange for a taxi, where to go and what it costs. And, really, it's no longer like - it feels more like travelling to Cologne. (Zülal, 59, 44)

This quotation from the narrative of Zülal, who was born in Germany in 1979 but still visits the country her parents emigrated from Turkey one or twice a year, shows that the relatively short time it takes to travel to Turkey is experienced as a reduction of geographical distance. Zülal has moreover become familiar with local practices and knowledge that make her travel activities easier. Thus, for Zülal, there is no big difference between travelling to Turkey, her parents' emigration country, and travelling to another city in Germany, such as Cologne.

Zülal is thus not only mobile between Germany and Turkey, she has also gained 'motility' [Kaufmann 2002]. While mobility means the actual physical movement, motility refers to the skills mobility requires. 'Motility can be defined as the capacity of a person to be mobile, more precisely, as the way in which an individual appropriates what is possible in the domain of mobility and puts this potential to use for his or her activities.' [Kaufmann 2002: 37; emphasis in the original] The concept of motility responds to the fact that people have a disposition for mobility that can be transformed into real mobility depending on their ambitions and circumstances. Such potential and resources also become visible in the context of migration, as one study has described in reference to elderly migrants. 'Migrants have the potential for mobility. This derives from the experiences and ability of mobility that migrants have acquired in the course of their frequent journeys and changes of residence before and after migration. They have resources for mo- 
bility, since they have social contacts, knowledge, and a more or less extensive material basis in both countries.' [Dietzel-Papakyriakou 1999: 154; author's translation]. Similarly, it can be assumed that migrants have the potential and skills of transnationality, having acquired them in the course of their life.

However, not only migrants but also their children develop the potential for mobility and transnationality [Reisenauer 2020]. They acquired the experiences of living in another country, mobility potential, language, and intercultural skills, as well as transnational social capital, when they were still just children. In this sense, it seems true that 'children's perspectives today will affect their practices in the future' [Gardner 2012: 901]. As they are socialised in both their (or their parents') emigration and immigration country, they develop a 'transnational habitus' [Vertovec 2009: 66-69]. 'By conceptualizing transnational experiences through the idea of habitus, social scientists might better appreciate how dual orientations arise and are acted upon. The notion also shines light upon the ways in which transnational life experiences may give rise not only to dual orientations but also to a personal repertoire comprising varied values and potential actionsets drawn from diverse cultural configurations.' [Vertovec 2009: 69] With the focus on migrant children, it is also worth asking how transnationality is intergenerationally transmitted and passed on from the first to the next generation. This question requires further research on migrant children in transnational settings.

All in all, the biographies of former migrant children suggest that migration and transnational experiences during childhood affect what people do later in life. If transnationality is also a phenomenon of the next generation, the question arises of whether there are differences between the transnational practices of different generations. It can be assumed that no 'automatic replication of the same forms of transnational life between generations' [Smith 2002] takes place. Rather, transnationality changes in successive generations, whereby in general frequency and intensity are more likely to decrease [Levitt, Waters 2002a]. However, this does not mean that Turkey remains just a holiday resort for migrant children later in life. Rather, it is also possible to observe migrant children assuming responsibility for transnational (moral) obligations - for example, when they continue remittances after the death of their parents [Rumbaut 2002]. Moreover, migrant children establish their own connections to Turkey, for occupational reasons among others, as the next section shows.

\section{Transnationality and the integration of the next generation}

Having observed that many Turkish migrant children continued transnational practices into adulthood, it remains to clarify the relationship between transnationality and the integration of the next generation. Therefore, first, I look at two case studies of the next generation, with a particular focus on their professional careers. Second, based on the case studies, I reflect on the implications the rela- 
tionship between transnationality and integration has for personal relationships, the labour market, and education.

Adnan was born in Turkey in 1972 and moved to Germany when he was less than a year old. Throughout his childhood in Germany, he never lost contact with his extended family in Turkey. After finishing school, he studied and worked in the United States, where he met and befriended international students from Turkey and gained some international experiences. He then moved on to work for an American company in Turkey. This was the first time that he did not experience Turkey as, in his words, a 'holiday Turk'. At the time of the interview, he had been back in Germany for three years and was working for a government agency. For him, his 'migration background' was not an obstacle to finding employment. On the contrary, it helped him to obtain his current job, where he has 'the opportunity to help shape integration policy' in Germany. However, his professional responsibilities do not relate exclusively to Germany. He also collaborates with political organisations and institutions in Turkey:

Professional contacts (with Turkey - author's note) have increased since I returned (to Germany - author's note) and started to work for the government. I'm engaged in integration policies, and there are a lot of issues that can only be resolved with the help of Turkey. (Adnan, 14, 10)

Unlike Adnan, Kamber is a German-born child of binational parents who met when his mother was on holiday in Turkey. He has dual citizenship and speaks both German and Turkish. Since childhood he has maintained regular contact with his grandmother and one of his aunts living in Turkey. He is always in touch with friends in Turkey, whom he knows from the holidays he spent at his parents' summer house. During his school time, Kamber completed a three-month internship at a company in Turkey. After doing voluntary work for various organisations in the area of migration and integration in Germany, he became the manager of a German-Turkish association. The association 'aims to provide a common ground between Germans and Turks' and most of its activities take place in the cultural sphere. Kamber's management position often involves dealing with business partners in Turkey:

As the manager of the house (German-Turkish association - author's note), I actually have to deal with Turkey almost every day, particularly with ministries and cultural organisations in Turkey. We work closely with foundations in the areas of the arts and culture in Istanbul. We're dealing with artists in Turkey all the time, we invite them to events. And also managers, record companies, whatever; you name it, in all kinds of areas. (Kamber, 34, 44)

Although they were born in different countries, both respondents mainly grew up in Germany and can be considered well integrated. Nevertheless, they have 
both maintained personal ties to Turkey through their life. What is more, they strengthened existing relationships and even built new ones. In Adnans case, his personal ties to Turkey increased while he was studying and working abroad. Moreover, his sister currently lives in Turkey, and his parents, who are now retired, are planning to return in the future. One of Kamber's contacts, a 'secondgeneration Turk', moved to Turkey and as well as their friendship they now also maintain a working relationship. The cases of Adnan and Kamber demonstrate that migrant children's personal ties to Turkey do not necessary decrease over the course of time. Rather, children who were raised in a transnational setting, are in a position to have a (personal) network that spans two or even more countries. 'Transnational ties to one's country of origin are generally assumed to be of less importance to the offspring of immigrants, since most second-generation youngsters have spent their entire lives in the destination county and only visited the country of origin for relatively restricted periods of time. [...] Nevertheless, there are also indications of the existence of relatively strong transnational ties in the second generation. One such indication is the incidence of transnational marriages with partners who lived in Turkey prior to marriage.' [Straßburger 2004: 211] All in all, a look at the next generation in the German-Turkish migration context shows that even if their life-world context and personal networks are increasingly in Germany, they also maintain stable transnational relationships.

Adnan and Kamber are both actively involved in the German employment market, and employment is attributed with playing a central role in successful structural assimilation [Esser 2001: 20]. While integration theorists believe that multiple integration, that is the integration in more than one labour market at the same time, is not really possible [Esser 2004: 48], both of their cases demonstrate that the next generation can recognise and take advantage of the opportunities that are available in both the German and Turkish labour markets. Adnan has worked, even if only for one year, in Turkey. In comparison, Kamber's employment experiences in Turkey are limited to a three-month internship. As well as working abroad, they have both made use of their ties to Turkey for their current professional activity in Germany. Moreover, interethnic relationships and knowledge, such as bilingualism and culture-specific skills, are supportive for their professional success, and, thus, contribute significantly to their integration in Germany. Conversely, integration into the immigration country can also reinforce transnational practices. This applies to Adnan's as well as Kamber's growing professional ties to Turkey resulting from their employment in Germany. While past theoretical approaches conceptualised integration in the immigration country and links to the (parents') home country as distinct and mutually exclusive, this article points to how constitutively interwoven the two processes are.

Like integration into the labour market, better education does not necessarily lead to a decrease in transnationality. While transnational personal relationships are maintained by the next generation regardless of migrant children's educational level, transnational practices in the area of work are mainly associated 
with the better educated. That transnationality is not commonly observed among marginalised migrants has also been shown by the 'Comparative Immigrant Entrepreneurship Project' (CIEP), carried out in the United States of America. This project found a positive correlation between transnational practices and a secondary or university level of education [Guarnizo, Portes, Haller 2003: 1229; Itzigsohn, Saucedo 2002: 782; Portes 2003: 884ff.]. At the same time, however, the CIEP project found that 'multiple integration' into different countries is not an exceptional situation only observed among specific groups of people, such as academics or artists. Rather, basically persons with different levels of education are transnational active and able to make use of transnational options for their personal and career opportunities. Thus, it can be stated that 'there is no unequivocal relation between migrants' transnational activities and structural integration. Transnational activities occur both among migrants with good and with marginalized social positions (in terms of educational level and labour market participation) in the host society' [Snel, Engbersen, Leerkes 2006: 300].

\section{Socialisation in transnational settings: directions for future research}

Although the TRANS-NET project was not directly focused on the socialisation of migrant children in transnational settings, the study achieved insights on how adult migrant children make sense of their past transnational childhood for their future life, especially with respect to their personal relationships and working life. However, to gain a proper understanding of transnationality at an early age, future research is required that will focus more specifically on children as active actors in migration processes and transnational contexts. To take children's narrative productions into account would, first, allow for a further differentiation of active transnational migrant children along the lines of intersectional categories such as socioeconomic status, age, and gender. Second, there is a need to examine the fragmented trajectories of transnational childhoods in more detail to identify the circumstances under which the positive and negative consequences of transnationality may potentially occur. For example, the present study focused on the role of the nuclear and extended family, while peer relations, which may be particularly relevant for children and youth, were neglected. Moreover, the impact of discrimination and racism on the processes of integration and transnationalisation has not yet been considered. All in all, while this article provides evidence of transnationality in childhood and consequently also demonstrates the relevance of this topic, future research should pay attention to the complexity of transnational experiences in childhood over the life course.

The TRANS-NET project revealed different tendencies in the relationship between transnationality and integration. On the one hand, a return orientation on the part of Turkish 'guest worker' parents in Germany and a transnational childhood can have negative effects on migrant children, in the form of family separations and educational obstacles. On the other hand, it was particularly re- 
markable in this regard to observe in the interviews the successful interplay that there is between transnationality and integration in the adult life of the next generations. Even for those in the 1.5 and second generations who are structurally well integrated in Germany, links to the emigration country (of their parents) do not necessarily lose their significance. On the contrary, for the well-integrated next generation it seems to be easier and more profitable to maintain transnational practices.

All in all, there is no clearly determinable relationship between transnationality and integration, but there are negative and positive variations of this interlinkage. ${ }^{5}$ Thus, the nature of the relationship must be determined for individual cases. Here it needs to be considered that one person's transnationality can have different effects on integration in various stages of his or her life. Moreover, while transnationality in one sphere of life can be positive for integration, the effect in other dimensions of life may be negative [Waldinger 2008: 9]. Instead of asserting one specific relationship between transnationality and integration for the next generation that can be considered generally valid, this article argues for a more precise analysis of the conditions in which transnationality can have positive or negative consequences for the 1.5 and second generation. A re-analysis of existing qualitative interviews with respondents in the next generation, with a new focus inspired by the DIWAN project, has put an emphasis on children and their socialisation in the migration process. This article established how transnational practices in childhood and in adulthood are interwoven. However, further research is required to analyse in more detail how transnational potential is accrued during childhood and transmitted and then carried into adulthood.

EVELINE REISENAUER is a researcher at the Munich-based German Youth Institute (DJI). She studied sociology at Ludwig Maximilian University in Munich and holds a PhD from Bielefeld University. She has participated in several national and international research projects on migration and transnationalisation, focusing especially on personal relationships and families. Her monograph Transnationale persönliche Beziehungen in der Migration (Springer VS, 2017) is based on her PhD thesis. She is also the co-author of Transnational Migration (with Thomas Faist and Margit Fauser, Polity Press, 2013).

\footnotetext{
${ }^{5}$ For various possible combinations, see Joppke and Morawska [2003] and Morawska [2004].
} 


\section{References}

Abadan-Unat, N. 1988. 'The Socio-Economic Aspects of Return Migration in Turkey.' Migration: A European Journal of International Migration and Ethnic Relations (3): 29-59.

Alba, R. D., J. Holdaway (eds.). 2013. The Children of Immigrants at School: A Comparative Look at Integration in the United States and Western Europe. New York: New York University Press, https://doi.org/10.18574/nyu/9780814760949.001.0001.

Apitzsch, U., I. Siouti. 2008. 'Transnationale Biographien.' Pp. 97-111 in H. G. Homfeldt, W. Schröer, and C. Schweppe (eds.). Soziale Arbeit und Transnationalität: Herausforderungen eines spannungsreichen Bezugs. Weinheim: Juventa.

Baldassar, L., L. Merla. 2014a. 'Introduction: Transnational Family Caregiving Through the Lens of Circulation.' Pp. 3-24 in L. Baldassar, L. Merla (eds.). Transnational Families, Migration and the Circulation of Care: Understanding Mobility and Absence in Family Life. New York: Routledge, https:// doi.org/10.4324/9780203077535.

Baldassar, L., L. Merla (eds.). 2014b. Transnational Families, Migration and the Circulation of Care: Understanding Mobility and Absence in Family Life. New York: Routledge, https://doi.org/10.4324/9780203077535.

Bryceson, D., U. Vuorela. 2002. 'Transnational Families in the Twenty-First Century.' Pp. 3-30 in D. Bryceson, U. Vuorela (eds.). The Transnational Family: New European Frontiers and Global Networks. Oxford: Berg, https://doi.org/10.4324/9781003087205-2.

Carlson, S. 2013. 'Becoming a Mobile Student: A Processual Perspective on German Degree Student Mobility.' Population, Space and Place 19 (2): 168-180, https://doi.org/10.1002/psp.1749.

Chan, K. B. 1997. 'A Family Affair: Migration, Dispersal, and the Emergent Identity of the Chinese Cosmopolitan.' Diaspora: A Journal of Transnational Studies 6 (2): 195-213, https://doi.org/10.1353/dsp.1997.0005.

Dietzel-Papakyriakou, M. 1999. 'Wanderung alter Menschen: Das Beispiel der Rückwanderung der älteren Arbeitsmigranten.' Pp. 141-156 in G. Naegele, R.-M. Schütz. Soziale Gerontologie und Sozialpolitik für ältere Menschen: Gedenkschrift für Margret Dieck. Wiesbaden: VS Verlag für Sozialwissenschaften, https://doi.org/10.1007/978-3-322-88923-2_10.

Erel, U. 2002. 'Reconceptualizing Motherhood: Experiences of Migrant Women from Turkey Living in Germany.' Pp. 127-146 in D. Bryceson, U. Vuorela. The Transnational Family: New European Frontiers and Global Networks. Oxford: Berg, https://doi.org/10.4324/9781003087205-9.

Esser, H. 2001. Integration und ethnische Schichtung. Vol. 40. Mannheim.

Esser, H. 2004. 'Welche Alternative zur "Assimilation" gibt es eigentlich?' Pp. 41-59 in K. J. Bade, M. Bommes. IMIS-Beiträge, vol. 23, Migration - Integration - Bildung: Grundfragen und Problembereiche. Osnabrück.

Esser, H. 2006. Sprache und Integration: Die sozialen Bedingungen und Folgen des Spracherwerbs von Migranten. Frankfurt am Main: Campus.

Faist, T. 2000. The Volume and Dynamics of International Migration and Transnational Social Spaces. Oxford: Oxford University Press, https://doi.org/10.1093/acprof:oso/9780198293910.001.0001.

Filsinger, D. 2011. 'Integration von Familien mit Migrationshintergrund.' Pp. 48-67 in: V. Fischer, M. Springer. Handbuch Migration und Familie: Grundlagen für die soziale Arbeit mit Familien. Schwalbach/Ts.: Wochenschau.

Fog Olwig, K. 2012. 'The Care Chain, Children's Mobility and the Caribbean Migration Tradition.' Journal of Ethnic and Migration Studies 38 (6): 933-952, https://doi.org/10.1080/1369183X.2012.677175. 
Fouron, G. E., N. Glick Schiller. 2001. 'The Generation of Identity: Redefining the Second Generation Within a Transnational Social Field.' Pp. 58-86 in H. R. Cordero-Guzmán, R. C. Smith, R. Grosfoguel (eds.). Migration, Transnationalization, and Race in a Changing New York. Philadelphia: Temple University Press.

Fürstenau, S. 2008. 'Transnationalität und Bildung.' Pp. 203-218 in H. G. Homfeldt, W. Schröer, C. Schweppe. Soziale Arbeit und Transnationalität: Herausforderungen eines spannungsreichen Bezugs. Weinheim: Juventa.

Fürstenau, S., H. Niedrig. 2007. 'Zum Schwerpunkt dieser Ausgabe: Jugendliche in transnationalen Kontexten.' Diskurs Kindheits- und Jugendforschung 2 (3): 235-245.

Gardner, K. 2012. 'Transnational Migration and the Study of Children: An Introduction.' Journal of Ethnic and Migration Studies 38 (6): 889-912, https://doi.org/10.1080/1369183X.2012.677170.

Gerdes, J., E. Reisenauer, D. Sert. 2012. 'Varying Transnational and Multicultural Activities in the Turkish-German Migration Context.' Pp. 103-157 in P. Pitkänen, A. Içduygu, D. Sert. Migration and Transformation: Multi-Level Analysis of Migrant Transnationalism. Dordrecht: Springer, https://doi.org/10.1007/978-94-007-3968-0_4.

Gjokaj, L., M. Baca Zinn, S. J. Nawyn. 2013. 'Connecting Family and Migration.' Pp. 283-294 in S. J. Gold, S. J. Nawyn. The Routledge International Handbook of Migration Studies. London: Routledge.

Goldring, L. 2004. 'Family and Collective Remittances to Mexico: A Multi-Dimensional Typology.' Development and Change 35 (4): 799-840, https://doi.org/10.1111/j.0012-155X.2004.00380.x.

Goulbourne, H., T. Reynolds, J. Solomons, E. Zontini. 2010. Transnational Families: Ethnicities, Identities and Social Capital. London: Routledge, https://doi.org/10.4324/9780203862186.

Guarnizo, L. E., A. Portes, W. Haller. 2003. 'Assimilation and Transnationalism: Determinants of Transnational Political Action Among Contemporary Migrants.' American Journal of Sociology 108 (6): 1211-1248, https://doi.org/10.1086/375195.

Guarnizo, L. E. 2003. 'The Economic of Transnational Living.' International Migration Review 37 (3): 666-699, https://doi.org/10.1111/j.1747-7379.2003.tb00154.x.

Haikkola, L. 2011. 'Making Connections: Second-Generation Children and the Transnational Field of Relations.' Journal of Ethnic and Migration Studies 37 (8): 1201-1217, https:/ / doi.org/10.1080/1369183X.2011.590925.

Haug, S. 2005. 'Arbeitsmigration, Familiennachzug, Heiratsmigration: Die zweite Einwanderergeneration und ihre Migrationsbiographie.' Pp. 77-95 in S. Haug, C. Diehl. Aspekte der Integration: Eingliederungsmuster und Lebenssituation italienischund türkischstämmiger junger Erwachsener in Deutschland. Wiesbaden: VS Verlag für Sozialwissenschaften.

Holst, E., A. Schäfer, M. Schrooten. 2012. 'Gender and Remittances: Evidence from Germany.' Feminist Economics 18 (2): 201-229, https://doi.org/10.1080/13545701.2012.692478.

Hondagneu-Sotelo, P., E. Avila. 1997. "“I'm Here, but I'm There”: The Meaning of Latina Transnational Motherhood.' Gender \& Society 11 (5): 548-571, https:// doi.org/10.1177/089124397011005003.

Itzigsohn, J., S. G. Saucedo. 2002. 'Immigrant Incorporation and Sociocultural Transnationalism.' International Migration Review 36 (3): 766-798, https://doi.org/10.1111/j.1747-7379.2002.tb00104.x.

Jones-Correa, M. 2002. 'The Study of Transnationalism Among the Children of Immigrants: Where We Are and Where We Should Be Headed.' Pp. 221-241 in P. Levitt, M. C. Waters (eds.). The Changing Face of Home: The Transnational Lives of the Second Generation. New York: Sage. 
Joppke, C. 1999. Immigration and the Nation-State: The United States, Germany, and Great Britain. Oxford: Oxford University Press, https://doi.org/10.1093/0198295405.001.0001.

Joppke, C., E. Morawska (eds.). 2003. Toward Assimilation and Citizenship: Immigrants in Liberal Nation-States. Houndmills, Basingstoke, Hampshire, New York: Palgrave Macmillan.

Kaufmann, V. 2002. Re-thinking Mobility. Avebury: Ashgate.

King, R., A. Christou. 2010. 'Diaspora, Migration and Transnationalism: Insights from the Study of Second-Generation “Returnees".' Pp. 167-183 in R. Bauböck, T. Faist. Diaspora and Transnationalism: Concepts, Theories and Methods. Amsterdam: Amsterdam University Press, https://doi.org/10.1002/ijpg.280.

King, R., E. Ruiz-Gelices. 2003. 'International Student Migration and the European "Year Abroad": Effects on European Identity and Subsequent Migration Behaviour.' International Journal of Population Geography 9 (3): 229-252.

Levitt, P., M. C. Waters. 2002a. 'Introduction.' Pp. 1-30 in P. Levitt, M. C. Waters. The Changing Face of Home: The Transnational Lives of the Second Generation. New York: Sage.

Levitt, P., M. C. Waters (eds.). 2002b. The Changing Face of Home: The Transnational Lives of the Second Generation. New York: Sage.

Martin, P. L. 1991. The Unfinished Story: Turkish Labour Migration to Western Europe: With Special Reference to the Federal Republic of Germany. Geneva: International Labour Office.

Mazzucato, V., D. Schans. 2011. 'Transnational Families and the Well-Being of Children: Conceptual and Methodological Challenges.' Journal of Marriage and Family 73 (4): 704-712, https://doi.org/10.1111/j.1741-3737.2011.00840.x.

Morawska, E. 2004. 'Exploring Diversity in Immigrant Assimilation and Transnationalism: Poles and Russian Jews in Philadelphia.' International Migration Review 38 (4): 1372-1412, https://doi.org/10.1111/j.1747-7379.2004.tb00241.x.

Pagenstecher, C. 1996. 'Die "Illusion" der Rückkehr: Zur Mentalitätsgeschichte von "Gastarbeit" und Einwanderung.' Soziale Welt 47 (2): 149-179.

Parey, M., F. Waldinger. 2008. Studying Abroad and the Effect on International Labor Market Mobility: Evidence from the Introduction of Erasmus. IZA Discussion Paper No. 3430. Forschungsinstitut zur Zukunft der Arbeit.

Parreñas, R. S. 2001. 'Mothering from a Distance: Emotions, Gender, and Intergenerational Relations in Filipino Transnational Families.' Feminist Studies 27 (2): 361-390, https:// doi.org/10.2307/3178765.

Phoenix, A. 2010. 'Adult Retrospective Narratives of Childhood Experiences of Serial Migration and Reunification with Mothers.' Finish Journal of Ethnicity and Migration 5 (2): 70-78.

Pitkänen, P., A. Içduygu, D. Sert (eds.). 2012. Migration and Transformation: Multi-Level Analysis of Migrant Transnationalism. Dordrecht: Springer, https:// doi.org/10.1007/978-94-007-3968-0.

Portes, A. 2003. 'Conclusion: Theoretical Convergences and Empirical Evidence in the Study of Immigrant Transnationalism.' International Migration Review 37 (3): 874-892, https://doi.org/10.1111/j.1747-7379.2003.tb00161.x.

Reisenauer, E. 2015. 'Experiencing "Close Strangers" and "Distant Intimates": Transnational Childhoods Between Turkey and Germany.' Transnational Social Review 5 (3): 258-273, https:/ / doi.org/10.1080/21931674.2015.1074782.

Reisenauer, E. 2020. 'Transnationale Identitätskonstruktionen im Migrationskontext.' Pp. 139-152 in P. Genkova, A. Riecken. Handbuch Migration und Erfolg: Psychologische und sozialwissenschaftliche Aspekte. Wiesbaden: Springer, https://doi.org/10.1007/978-3-658-18236-6_7. 
Rohr, E., M. M. Jansen, J. Adamou (eds.). 2014. Die vergessenen Kinder der Globalisierung: Psychosoziale Folgen von Migration. Gießen: Psychosozial, https://doi.org/10.30820/9783837969061.

Rumbaut, R. G. 2002. 'Severed or Sustained Attachments?: Language, Identity, and Imagined Communities in the Post-Immigrant Generation.' Pp. 43-94 in P. Levitt, M. C. Waters (eds.). The Changing Face of Home: The Transnational Lives of the Second Generation. New York: Sage.

Schmidt, G. 2011. 'Law and Identity: Transnational Arranged Marriages and the Boundaries of Danishness.' Journal of Ethnic and Migration Studies 37 (2): 257-275, https:// doi.org/10.1080/1369183X.2011.521339.

Smith, R. C. 2002. 'Life Course, Generation, and Social Location as Factors Shaping Second-Generation Transnational Life.' Pp. 145-167 in P. Levitt, M. C. Waters. The Changing Face of Home: The Transnational Lives of the Second Generation. New York: Sage.

Snel, E., G. Engbersen, A. Leerkes. 2006. 'Transnational Involvement and Social Integration.' Global Networks 6 (3): 285-308, https://doi.org/10.1111/j.1471-0374.2006.00145.x.

Stenzel, A., H. G. Homfeldt. 1985. Auszug in ein fremdes Land?: Türkische Jugendliche und ihre Rückkehr in die Türkei. Weinheim, Basel: Beltz.

Straßburger, G. 2004. 'Transnational Ties of the Second Generation: Marriages of Turks in Germany.' Pp. 211-231 in T. Faist, E. Özveren (eds.). Transnational Social Spaces: Agents, Networks and Institutions. Aldershot: Ashgate.

Suârez-Orozco, C., I. L. G. Todorova, J. Louie. 2002. 'Making up for Lost Time: The Experience of Separation and Reunification Among Immigrant Families.' Family Process 41 (4): 625-643, https://doi.org/10.1111/j.1545-5300.2002.00625.x.

Vertovec, S. 2009. Transnationalism. London: Routledge, https://doi.org/10.4324/9780203927083.

Waldinger, R. 2008. 'Between "Here" and "There": Immigrants Cross-Border Activities and Loyalties.' International Migration Review 42 (1): 3-29, https:// doi.org/10.1111/j.1747-7379.2007.00112.x.

White, A., C. Ní Laoire, N. Tyrrell, F. Carpena-Méndez. 2011. ‘Children's Roles in Transnational Migration.' Journal of Ethnic and Migration Studies 37 (8): 1159-1170, https://doi.org/10.1080/1369183X.2011.590635.

Wilhelm, G. 2011. Generation Koffer: Die zurückgelassenen Kinder. Berlin: Orlanda.

Zielke-Nadkarni, A. 2003. 'The Meaning of the Family: Lived Experiences of Turkish Women Immigrants in Germany.' Nursing Science Quarterly 16 (2): 169-173, https://doi.org/10.1177/0894318403251797. 